\title{
Internet use in schools in Alberta, Canada: Implications for school librarians
}

\section{Oberg, Dianne;Gibson, Susan}

International Association of School Librarianship. Selected Papers from the ... Annual Conference; 2000;

\section{Internet Use in Schools in Alberta, Canada: Implications for School Librarians}

\author{
Dianne Oberg and Susan Gibson
}

The findings of this quantitative investigation of the use of the Internet in Alberta schools confirmed the findings of earlier studies. The survey asked teachers and principals about their preparation for using the technology and the provision of adequate hardware and software and opportunities for professional development. The majority of respondents felt positively about the Internet as a teaching and learning tool, and many were exploring its use through trial and error. The findings also suggest that there is need and opportunity for school librarians to take a stronger role in supporting Internet use in schools, and the authors offer useful strategies for this goal.

\section{Introduction}

A number of initiatives coming from the provincial and federal governments have encouraged schools in Alberta, Canada to connect to the Internet and to use the Internet. The provincial government has funded access to the Internet in schools as well as a professional development program for teachers, the TELUS Learning Connection (see, http://www.2learn.ca).

This quantitative study is one phase of a long-term research program examining Internet use in schools and the factors that facilitate and limit that use. It extends research that began in 1997 and has now been expanded to a national study. In the initial phase of the program of research, January-April 1997, a case study approach was used to collect data on how six elementary and secondary schools were using the Internet and how teachers were learning to use it, as well as data on the perceptions of educators and parents of its value as an educational tool (Gibson \& Oberg, 1997). The teachers interviewed for these case studies, no matter what their experience level with the Internet, were frustrated by the vast amount of information available and by their lack of search skills and strategies for dealing with it (Gibson \& Oberg, 1998a). The researchers continued their work in these schools through collaborative research partnerships in which individual teachers, both novice and experienced Internet users, were paired with graduate students trained in Internet use. The focus of these research partnerships was to examine ways to improve the teachers' search skills and to assist them in integrating the Internet into their teaching (Gibson \& Oberg, 1998b; Gibson \& Oberg, 1998c). 


\title{
Part V. Contributors
}

\section{Contributors to the Fourth International Forum on Research in School Librarianship}

\begin{abstract}
Abrizah Abdullah has worked in a number of schools as well as the Educational Policy Planning and Research Division. Ministry of Education in Malaysia. She is currently a Lecturer at the Faculty of Computer Science and Information Technology at the University of Malaya in Kuala Lumpur, Malaysia. Email: abrizah@fsktm.um.edu.my.
\end{abstract}

Marlene Asselin is a member of the Department of Language and Literacy Education in the Faculty of Education at the University of British Columbia, Canada. She coordinates the Diploma and Graduate Programs in Teacher-Librarianship, and her research areas of interest include reader response, resource-based learning, and the social dimensions of literacy. Email: marlene.asselin@ubc.ca.

Susan Gibson is Associate Professor in the Faculty of Education at the University of Alberta, Canada. Her ongoing research includes studies of collaborative research and the implementation and integration of the Internet into elementary and secondary schools. Email: sgibson@ualberta.ca.

Ken Haycock is Director of the graduate School of Library Archival and Information Studies at the University of British Columbia in Vancouver, Canada. He has been a teacher, teacher-librarian, and school principal as well as senior education official. From 1995-1997 he was the elected chair of the West Vancouver (Canada) School Board, and from 1995-2000 he served as Executive Director of the International Association of School Librarianship. Email: ken.haycock@ubc.ca

James E. Herring is Head of the Department of information Management at Queen Margaret University College, Scotland. He is the author of books and articles on school librarianship, information skills, and the use of the Internet in schools. He is currently researching the impact of school intranets on the role of the school librarian. Email: iherring@QMUC.ac.uk.

Eleanor B. Howe has served as librarian and taught in both elementary and secondary schools in the United States. Her interests include action research, implementing technology, and creating school library programs that contribute to the learning of students. She has published and presented articles and sessions at the local, state, national, and international levels. Email: howe@washington.k12.pa.us; ehowe@bellatlantic.net.

Jo-Anne Naslund is the Instructional Programs Librarian at the Education Library in the Faculty of Education at the University of British Columbia, Canada. She has worked as a teacher-librarian and a teacher of English and physical education. Her research interests include resource-based learning, reading interests, and children's literature. Email:

Joanne.naslund@ubc.ca. 
Simon Naylor, a physics teacher at Ripon Grammar School in England, has a keen interest in developing information skills in pupils who are studying science in secondary school. He is also active in developing instructional websites at the school. Email: simon.naylor@easynet.co.uk.

Dianne Oberg is Professor in the Department of Elementary Education, Faculty of Education at the University of Alberta, Canada. Her research interests include the use of libraries in schools, collaborative research, and the implementation and integration of the Internet into elementary and secondary schools. She also serves as editor of School Libraries Worldwide. Email: doberg@ualberta.ca.

Diljit Singh has taught in two schools as well as worked at the state and federal levels of the Ministry of Education. He is currently an Associate Professor at the Faculty of Computer Science and Information Technology at the University of Malaya in Kuala Lumpur, Malaysia. Email: diljit@fsktm.um.edu.my.

Gray Southon is Senior Lecturer in Knowledge Management in the Department of Information Studies at the University of Technology Sydney, Australia. He is engaged in two research projects exploring knowledge and the role of information professionals in organisations. Of particular interest are the dynamics of knowledge and how organisations create effective knowledge-sharing cultures. Email: Gray.Southon@uts.edu.au.

Anne-Marie Tarter, school librarian at Ripon Grammar School in England, has presented papers on information skills and the Internet in school libraries. She has also developed instructional websites, linked to the school library web pages, in her school. Email: tarters@globalnet.co.uk.

Ross Todd is Head of the Department of Information Studies at the University of Technology Sydney, Australia. He is engaged in two research projects exploring knowledge and the role of information professionals in organisations. Of particular interest are the dynamics of knowledge and how organisations create effective knowledge-sharing cultures. Email: Ross.Todd@uts.edu.au.

\section{Contributors to the Proceedings}

Claus Berg has since 1996 been in the Danish Ministry of Education working with the Sektornet," the national educational network in Denmark. He has also been a teacher who has been involved with Internet-based collaborative projects since 1990. He has spoken in Europe, South America, and the United States. Email: claus.berg@uvm.dk.

Kay Bishop has had over 20 years of experience as a school library media specialist and currently teaches courses in school media and youth services at the University of South Florida where she is also associate director of the School of Library and Information Science. Email: bishop kay@hotmail.com.

Margaret Butterworth worked in Singapore from 1980-84 as a librarian and from 199396 as Lecturer at Nanyang Technological University where she helped to establish a Masters course in librarianship. She is now completing a $\mathrm{PhD}$ at Curtin University and is an active member of the West Australian School Library Association. Email:

Margaret@iinet.net.au. 


\section{The Research Questions}

The overall program of research on Internet use in Alberta schools has been guided by three overarching research questions:

1. What is the extent and nature of Internet use in Alberta schools?

2. How have teachers and principals learned about the Internet?

3. What factors influence the extent and nature of Internet use in Alberta schools?

\section{Design and Methodology of the Internet Use Survey}

The quantitative investigation was designed to test on a larger scale the findings of three earlier small-scale qualitative studies. It used computer-scored questionnaires that were based on the findings of the earlier studies. The questionnaires consisted of 72 items, including Likert scale rating items and yes/no items. Participants provided data related to the size of their school, the nature of their school community, their educational background and work experience, and their Internet knowledge, access, and use. The questionnaire packages were mailed to 300 elementary and secondary schools in Alberta in March 1998. The sample was generated from a listing of Alberta's operating schools for the 1997-1998 school year. The questionnaire package was mailed to the principal who was asked to have the surveys completed by a principal in the school, by a teacher who was an experienced Internet user, and by a teacher who was a beginning Internet user. Postage-paid addressed return envelopes were provided for each of the survey participants.

Questionnaire data were computer scanned and analyzed using SPSS 6.1, version 8.0. Chi-square testing was used to establish levels of significance of findings. In this report of the findings, demographic data were reported in percentages. Responses to Likert scale rating questions were collapsed from a five-point to a three-point scale. For example, the Never and Rarely responses and the Frequently and Regularly responses were combined from the scale Never/Rarely/Sometimes/ Frequently /Regularly. This approach was used because these response pairs are conceptually very similar and because the number of missing cases from a five-point scale would preclude valid chisquare testing for significant difference. Only significant differences at $p<.001$ are reported here. This very conservative $p$ value is being used because of the multiple comparisons that were completed; this should have minimized the Type I error rates in the analysis.

\section{Survey Responses}

The results of the survey are summarized here; for a fuller report of the findings, readers may want to consult an article recently published on this study (Gibson \& Oberg, 1999). 


\section{Participant Demographics}

The overall response rate was 52\%: 166 principals and 300 teachers returned the questionnaires. Generally, the participants and their schools (the achieved sample) appeared to be a representative sample of Alberta educators and their schools. Survey responses were received from $11 \%$ of Alberta's elementary schools, $11 \%$ of schools serving both elementary and secondary students, and $9 \%$ of the secondary schools. Of the 166 principals who responded to the survey, $36 \%$ headed elementary schools, $34 \%$ headed mixed elementary-secondary schools, and $25 \%$ headed secondary schools; $5 \%$ did not complete this question. There was no under- or over-representation of schools at particular grade levels. Most (82\%) of the survey participants worked in schools with 500 or fewer students.

The participants appeared to be fairly typical of Alberta's teaching force. In 1998, Alberta's educators had an average age of 41.01 years and had an average of 14.97 years of teaching experience. Most of the survey participants were in their $40 \mathrm{~s}$ and had 15 or more years of experience in education. The principals were mostly males $(68 \%)$ in their $40 \mathrm{~s}(44 \%)$ with more than 15 years experience in education $(76 \%)$. The teachers were mostly females $(56 \%)$ in their $40 \mathrm{~s}(35 \%)$ with more than 15 years experience in education $(42 \%)$.

\section{Participant Responses}

The majority of the teacher participants indicated that they believed that the Internet is an important tool for teaching (78\%) and for student learning $(76 \%)$. The principal participants were slightly more positive about the importance of the Internet for teaching $(86 \%)$ and for student learning $(83 \%)$.

Personal interest was the primary motivating factor for learning about the Internet, and trial and error was the most frequently reported approach to learning. Principals were more positive than teachers about the adequacy of school and district support for Internet use. Principals used the Internet mostly for e-mailing colleagues and for accessing district and ministry information, while teachers used it mostly for finding instructional materials. Fewer than $40 \%$ of the teachers engaged their students in Internet use for more than one hour a week.

The participants were evenly divided between experienced and novice users.

Experienced and novice users differed significantly mainly on how they used the Internet in their professional work and in their personal desire to learn about the Internet. Principals who were experienced Internet users were more likely to use e-mail to access district information and professional development information. Teachers who were experienced Internet users were more likely to search for lesson information and teaching materials on the Web and more likely to engage their students in searching for information on the Web, in going on virtual field trips, in communicating with others by e-mail, and in creating multimedia projects.

Principals reported that they facilitated teacher learning about the Internet through providing access to staff in-service, designating information and technology specialists for their schools, conducting staff in-service, and providing financial support and release time for teacher learning. They also provided other kinds of support such as ensuring that hardware was maintained, allocating funds to upgrade hardware and/or software, and supporting the development of a school website. The majority of teacher participants viewed their principals as supportive of Internet use. 
Teachers indicated the extent to which various obstacles limited their use of the Internet. The most frequently reported obstacles were limited time available for using the Internet, pressure to cover the curriculum, lack of school funds to purchase or upgrade hardware and/or software, and limited access to computers connected to the Internet. Teachers viewed problems related to the Internet itself or to their skills in using the Internet as less limiting factors. Less than a quarter of the teacher participants identified concerns related to relevance of information, reliability of information, the nature of information on the Internet, and limited skills in using search engines and/or search strategies on the Internet. This suggests that most of the teacher participants were in the early stages of technology implementation. Their concerns were how to use the technology of the Internet rather than how to integrate the Internet into the curriculum and how to use it to benefit student learning.

The results of this survey, as well as the case studies conducted in earlier phases of the research, suggest that teachers need time to learn the intricacies of the Internet but that time alone will not address all of the learning issues. Guided exploration, collegial sharing of integration strategies, and one-on-one support from information specialists such as school librarians are some of the approaches to learning that will maximize teacher learning time. In-service programs for teachers must be carefully planned to allow for hands-on practice and discussion both during and following the sessions. Principal and district support for learning is as crucial as providing easy access to the technology.

\section{Relationship to Other Research}

The body of research addressing Internet use in education remains quite small. The research that has been done to date suggests that the benefit to students of using new technologies such as the Internet is greatly dependent on the technological skill of the teacher and the teacher's attitude to the presence of the technology in teaching (Grégoire, Bracewell, \& Laferrière, 1996; Peha, 1995). Other factors influencing effective use of the Internet include the availability of sophisticated technology in terms of hardware and software (Maddux, 1994), the support for teacher learning (Hack \& Smey, 1997; Honey \& McMillan, 1993; Woodrow, 1991), and the adoption of new models of teaching and learning (Hooper \& Rieber, 1995; Follansbee, Gilsdorf, Stahl, Dunfey, Pisha, \& Hughes, 1996). Although the use of the Internet can change teachers' attitudes towards the computer as an instructional tool and can encourage them to restructure their classes, continued and effective use requires ongoing training, technical support, home access, and time to learn how to incorporate it into teaching (Gallo \& Horton, 1994; Honey \& McMillan, 1993). Contributing to the intricacy of the Internet as a learning environment for teachers are factors such as the ambiguity, unpredictability, lack of structure, lack of selectivity, and variable information quality that characterize the Internet (McNicholas \& Todd, 1996; Todd, 1996). A technology such as the Internet places demands on schools in terms of infrastructure development and teacher learning, and schools and teachers need time to address these demands. The research literature suggests a five year implementation period for any major change of this nature (Fullan, 1991; Robinson, 1995).

The findings of our program of research on Internet use in Alberta schools were consistent with the research cited above. There was little evidence of schools and teachers having adopted the changes in teaching and learning that support more student-centered learning with technology. Hooper and Reiber's five-stage model of technology implementation (familiarization, utilization, integration, reorientation, and evolution) provides a useful framework for analysis of data from the program of research. Many of the teachers in our case study/research partnership schools were in the familiarization 
phase that involves initial exposure to and experience with a technology or innovation. They were interested in the Internet and its potential but they had not attempted to use it in their teaching. Others were in the utilization phase; these teachers were trying out the Internet and expressing concerns about "making it work" in their teaching. As was evident in our case study/research partnership schools, difficulties with using the technology and/or disruptions of classroom routines had resulted in abandonment of Internet use for some teachers. A few teachers were involved in the integration phase; they were using the Internet in purposeful ways to achieve particular teaching and learning tasks but not making any real changes in the traditional roles of student and teacher. A few teachers were aware of the potential for a reconsideration and reconceptualization of classroom tasks and teacher roles (reorientation phase), but none appeared to have moved into this phase in their Internet use. There was no evidence of the development of a change in classroom environment as a result of the ways in which a new technology had been used (evolution phase).

Many teachers were frustrated by the vastness of the Web and were unaware of much of what was available on the Internet. Teachers, even those who were experienced Internet users, had little knowledge of the search engines and search strategies needed to make efficient use of Internet resources. Factors within the school context that influenced the teachers' willingness to learn about and use the Internet included the location of Internet access in the school, the capabilities of available computers, the vision and support of the administration, and the support of the community. The teachers' level of Internet knowledge and amount of prior experience influenced their willingness to use it. Although teachers were assisted in learning to use the Internet by collegial sharing, their learning was limited by a lack of both time and suitable in-service opportunities. For the teachers in our studies, learning about the Internet was a highly individualized activity that took place on the edges of their teaching lives. Rarely did we find evidence of effective staff development for teachers' learning about Internet use. For example, only one of our six case study/research partnership schools was characterized by the kind of school-based teacher learning support that is identified in the effective schools research.

This survey of principals and teachers in Alberta schools confirmed with quantitative data most of the patterns identified in the case studies and research partnerships. One pattern that was not confirmed by this quantitative data was teachers' concerns about the Internet itself or their skills in using it. This might be attributed to their early stage in technology implementation. Two studies looking at Alberta teachers' use of conventional library resources found the same puzzling phenomenon (Oberg, 1993; Oberg. 1996). Teachers, both novices and veterans, had received little libraryrelated instruction, but they reported high confidence levels in relation to the knowledge needed to provide their students with library-related instruction. Many appeared to be quite confident that they had sufficient knowledge to be able to teach their students how to evaluate materials for use $(52.6 \%)$, how to locate library materials $(77.2 \%)$, and how to use library materials in research projects $(81.8 \%)$ even though they had completed no courses in resource-based learning or library instruction or had, in only a few instances, received course-related library instruction on a regular basis in university $(18.2 \%)$ or in high school (3.1\%).

Less than a quarter of the teacher participants in the Internet use study identified concerns related to relevance of information, reliability of information, the nature of information on the Internet, and limited skills in using search engines and/or search strategies on the Internet. Could it be that they have quite a different understanding from that of the researchers and that of teacher-librarians of the sophisticated information skills that are required to use the Internet and to teach their students how to use the Internet for learning? Could it be they do not yet recognize the complexity of the Internet and that 
they do not see the need for the specialized library and information knowledge of the school librarian?

\section{Implications for School Librarians}

Ready access to technology is a necessary but not sufficient condition for teachers' learning about and increased use of the Internet with students. Teachers need the collaborative support and information-seeking expertise of school librarians if they are to use the Internet in ways that support and enhance student learning. School librarians who are knowledgeable about the Internet, professional development, and the curriculum can play an important role in addressing teachers' concerns about Internet use. School librarians new to the Internet and the issues it raises can find useful information and advice in resources such as the books by Clyde (1997), MacDonald (1997), and Berger (1998) and the proceedings of the ITEC and ISIS virtual conferences (see, for example, Hay \& Henri, 1996; Hay \& Henri, 1997).

The authors have drawn on the literatures of research and practice for the suggestions provided below and in earlier articles (Oberg \& Gibson, 1998; Oberg \& Gibson, 1999). These strategies for supporting more effective Internet use in schools are offered for consideration:

\section{Building Support for Using the Internet}

School principals are key to implementation initiatives including those related to information literacy (see, for example, Oberg, 1999). The Internet use studies showed that the attitude and support of school principals directly affected teachers' enthusiasm for Internet use in the school. Therefore, school librarians should discuss their support of teachers with the school principals and encourage them to give visible encouragement for Internet use. Because teachers' use of the Internet in school was highly correlated with home use and because Internet skill and comfort levels tended to be much higher among teachers who were online at home, principals and districts should consider programs that support teachers' having access to computers at home. To encourage community support, school librarians might also work to offer in-service programs for parents that show them how to use the Internet and that demonstrate how it is being used as educational tool in the school.

\section{Increasing Access to and Availability of Internet}

School librarians need to work with their school administration and/or technology planning teams to establish the most efficient and effective ways of organizing access to the technology. School librarians, experienced with flexible scheduling and providing access to resources, can help teachers and principals to create large blocks of time for teachers and students to use Internet computers in ways that are effective for learning (McKenzie, 1998). Schools need to provide Internet hookups that are consistent with best opportunities for student learning, and, as McKenzie points out, many different technology configurations can provide for student learning. School librarians need to work as members of a collaborative school team to develop action-specific long-range technology plans that include resources for maintaining and upgrading computers.

\section{Enhancing Levels of Internet Skills}

School librarians need to help teachers to understand the nature of the Internet and to develop time-saving search strategies. This is the opportunity to teach Boolean search strategies that are essential to information retrieval in other electronic environments such 
as the OPAC. School librarians should not assume anything about teachers' Internet knowledge and skill. They should conduct needs assessments before planning small group and focused in-service sessions for teachers because teachers in any one school are likely to vary greatly in Internet knowledge and searching skills. If only large group inservices are possible, school librarians might begin with an overview of important search skills and then provide opportunities for experienced users and non-users to work and learn together. Schools need to develop a vision for how the Internet might enhance teaching and to emphasize integration strategies rather than tools.

\section{Ensuring Information Quality and Relevance}

School librarians can support the integration of Internet resources into instruction by searching for and sharing with teachers the websites that are relevant to their work with students. These websites might be shared by means of a library web page or diskettes of bookmarks to be loaded on computers in classrooms or labs. School librarians can encourage teachers to share bookmarked sites with each other. This reduces teachers' search time, keeps teachers abreast of what's new on the Internet, and encourages non-users to begin using the Internet. Because teachers are often pressed for time but welcome new resources to enhance student interest and involvement, school librarians should begin by finding Internet resources that enrich teaching units that are already in use.

\section{Increasing Opportunities for Learning to Use the Internet}

School librarians need not only to take the lead in providing in-service on Internet skills but also to work with the school principals and teachers to find time for teacher exploration in addition to school level and district level in-services. Having a well thought out long-term technology plan with considerable staff input tends to move a school closer to implementing the goals of information literacy. Team members need to be aware that $30 \%$ of any technology budget should be allotted for staff development and that it takes from three to six years for teachers to integrate a new technology into their teaching (President's Committee of Advisors, 1997).

\section{Conclusions}

Teachers and principals in Alberta express a great deal of enthusiasm about the potential of the Internet for enhancing teaching and learning. From the perspective of knowing what the Internet offers and how to utilize the Internet for enhancing teaching and learning, however, most of the teachers and principals were really at the familiarization stage of Internet use. They were still trying to discover what was out there and how to negotiate their way through the maze of information. While the use of the Internet has the potential to encourage them to rethink approaches to teaching, that potential has only begun to be realized. School librarians can have a major role in helping schools realize that potential but they will need more than their specialized library and information knowledge. They will also have to be aware of the complexities of implementing change in schools. One of those complexities might be the extent to which teachers and principals are unaware of the need for the specialized expertise of the school librarian. 


\section{References}

Berger, P. (1998). Internet for active learners: Curriculum-based strategies for K-12. Chicago: ALA.

Clyde, L. A. (1997). School libraries and the electronic community: The Internet connection. Lanham, MD: Scarecrow Press.

Follansbee, S., Gilsdorf, N., Stahl, S., Dunfey, J., Pisha, B., \& Hughes, B. (1996). The role of on-line communications in schools: A national study. Peabody, MA: Center for Applied Special Technology. Available online: <http://www.cast.org $>$.

Fullan, M. (1991). The new meaning of educational change. London: Cassell.

Gallo, M., \& Horton, P. (1994). Assessing the effect on high school teachers of direct and unrestricted access to the Internet: A case study of an east central Florida high school. Educational Technology Research and Development, 42(4), 17-39.

Gibson, S., \& Oberg, D. (1997, June). Case studies of Internet use in Alberta schools: A summary report for the Alberta Advisory Committee for Educational Studies. Alberta Teachers Association, Edmonton. Available online: <http/l:www.ualberta.ca/ segibson>

Gibson, S., \& Oberg, D. (1998a). Learning to use the Internet: A study of teacher learning through collaborative research partnerships. Alberta Journal of Educational Research, 44(2), 239-241.

Gibson, S., \& Oberg, D. (1998b). Learning through collaborative research partnerships: Elementary school projects. Unpublished report, University of Alberta, Faculty of Education, Edmonton.

Gibson, S., \& Oberg, D. (1998c). Leaming through collaborative research partnerships: Secondary school projects. Unpublished report, University of Alberta, Faculty of Education, Edmonton.

Gibson, S., \& Oberg, D. (1999). What's happening with Internet use in Alberta schools? Alberta Journal of Educational Research, 65(3), 239-252.

Gregoire, R., Bracewell, R., \& Laferriere, T. (1996). The contribution of new technologies to learning about teaching in elementary and secondary schools. Collaboration of Laval University and McGill University. Available online: <http//www.tact.fse.ulaval.ca/fr/html/impactnt.html>.

Hack, L., \& Smey, S. (1997). A survey of Internet use by teachers in three urban Connecticut schools. School Library Media Quarterly, 25(3), 151-155.

Hay, L., \& Henri, J. (Eds.). (1996). A meeting of the minds: ITEC Virtual Conference proceedings. Belconnen, Australia: ASLA Press.

Hay, L., \& Henri, J. (Eds.). (1997). A meeting of the minds2: ITEC Virtual Conference proceedings. Belconnen, Australia: ASLA Press.

Honey, M., \& McMillan, K. (1993). Case studies of K-12 educators' use of the Internet: Exploring the relationship between metaphor and practice. New York: Education Development Center for Children and Technology. (ERIC Document Reproduction Service No. 372 726).

Hooper, S., \& Rieber, L.P. (1995). Teaching with technology. In A. C. Omstein (Ed.), Teaching: Theory into practice (pp. 155-170). Boston: Allyn and Bacon.

Maddux, C. (1994). The Internet: Educational prospects and problems. Educational Technology, 34(7), 3742. 
MacDonald, R. M. (1997). The Internet and the school library media specialist: Transforming traditional services. Westport, CT: Greenwood.

McKenzie, J. (1998) The wired classroom: Creating technology enhanced student-centered learning environments. From Now On: The Educational Technology Journal, 7(6). Available online: <http://fromnowon.org/mar98/flotilla.html\#anchor276463>, May 12, 1998.

McNicholas, C., \& Todd, R. (1996). New kids on the box: Is it worth the effort and investment? Scan, $15(4), 40-43$.

Oberg, D. (1996, August). So little instruction: Use of libraries in schools. Paper presented at the annual conference of the International Association of School Librarianship, Ocho Rios, Jamaica.

Oberg, D. (1993). Use of libraries in teaching by novice and experienced teachers. School Libraries in Canada, 13(3), 14-19.

Oberg, D., \& Gibson, S. (1999). Teachers and the Internet: How information literate are they? ISIS'99 (Information Services in Schools) Online Conference. Available: http://www.csu.edu.au/research/scstl/isis/participants/papers/, August 1999

Oberg, D., \& Gibson, S. (1998). Teachers' concerns about the Internet: Implications for teacher librarians. Scan, $17(3), 48-53$.

Peha, J. (1995). How K-12 teachers are using computer networks. Educational Leadership, 53(2), 18-25.

President's Committee of Advisors on Science and Technology, Panel on Educational Technology. (1997, March). Report to the President on the use of technology to strengthen K-I2 education in the United States. Available online : <http://www.whitehouse.gov/WH/EOP/OSTP/NSTC/PCAST/k12ed.html>, May 15, 1998

Robinson, B. (1995). Teaching teachers to change: The place of theory in the technology education of teachers. In D. A. Wills, B. Robin, \& J. Wills (Eds.), Technology and teacher education annual (pp. 40 -44). Association for the Advancement of Computing in Education.

Todd, R. (1996). How students evaluate Internet information services. In L. Hay \& J. Henri (Eds.), A meeting of the minds: ITEC Virtual Conference proceedings (pp. 157-159). Belconnen, Australia: ASLA Press.

Woodrow, J. (1991). Teachers' perceptions of computer needs. Journal of Research on Computing in Education, 23(4), 475-493. 